\title{
АНАЛИЗ ЭФФЕКТИВНОСТИ РЕЗУЛЬТАТОВ ЭЛЕКТРОМАГНИТНЫХ ЗОНДИРОВАНИЙ С РАЗЛИЧНЫМИ ИСТОЧНИКАМИ ПРИ ПОИСКАХ УГЛЕВОДОРОДОВ В УСЛОВИЯХ ЮГА СИБИРСКОЙ ПЛАТФОРМЫ
}

Агафонов Ю.А., Поспеев А.В., Кояпаниеи С.В., Оивховик Е.А. (ЗАО «Нркутское электроразведочное предприятие», г. Иркутск)

В течение последних десяти лет значительно улучшилась изученность Восточной Сибири геофизическими методами. С целью повышения тофности прогноза и снижения неоднозначности решения задач при поисках углеводородов в комплексе с сейсморазведкой пирокое развитие получили электроразведочные методы исследований, такие как зонджрования становлением поля в ближней зоне (ЗСБ) и дифференциально-нормированный метод электроразведки (ДНМЭ).

В настоящее время с достатонной пространственной плотностью изучен геоэлектрический разрез осадочного чехла на территории юга Сибирской платформы в зоне влияния трубопровода «Сибирь Тихий океан). Определены геоэлектрические параметры пород ордовика, верхоленской, литвинцевской, ангарской свит, бельско-булайского комплекса, усольской свиты и подсолевых отложений. На основе использования статистических данных по граничным величинам проводимости классов пород коллектор/неколлектор оценена вероятность налишия зон с улучшенными коллекторскими свойствами по этажам разреза.

В методе ЗСБ в качестве источника электромагнитного поля используется незаземленная петля, в ДНМЭ изучается поле, возбуждаемое заземленной электрической линией. Особенности геологического строения юга Сибирской платформы и петрофизические предпосылки позволяют с помощью электромагнитных методов ЗСБ и ДНМЭ детапьно изучить разрез и оценить распределение геоэлектрических параметров, как по глубине, так и по латерали.

Совместное рассмотрение накопленного фактического материала и результатов работ методами ЗСБ и ДНМЭ на общих участках позволяют комплексно сопоставить и проанализировать геологогеофизическую информативность методов. Наглядным является представление данных в едином масштабе, построение графиков, геоэлектрических разрезов по данным ЗСБ и ДМНЭ, разрезов коэффициента поляризуемости по данным ДНМЭ.

Информативным представляется сопоставление результатов зондирований в виде графиков сопротивления построенных для разных глубин, а также графики суммарной проводимости осадочного чехла, рассчитанные по геоэлектрическим моделям. Как правило, уровень значений рЗСБ и рДНМЭ на одной глубине по линиям профилей отличается весьма значительно, отклонение часто достигает порядка величин. Природа имекщихся различий может быть обусловлена особенностями зондирований с использованием различных типов источников и приемников поля (индукционного типа в ЗСБ и электрического типа в ДНМЭ), т.е. их различной чувствительностью к анизотропии разреза, латеральным неоднородностям, наличию высокоомных экранов (например, мощных пластов солей).

Можно сделать вывод о том, что метод ЗСБ имеют больпую чувствительность к изменению электрицеского сопротивления, более высокую глубинность исследований и разрешающую способность по глубине. Электрическое сопротивление, определяемее по результатам ЗСБ четко связано с литологическим составом горизонтов осадочного чехла, флюидонасыщением коллекторов. Данные ЗСБ менее подвержены влиянию анизотропии и локальньг геоэлектрических неоднородностей, не пувствительны к непроводящим экранам, индукиконный источник и приемник поля - незаземленная петля - не требует заземлений, что особенно актуально в условиях юга Сибирской платформы.

Метод ДНМЭ имеет высокую чувствительность к поляризационным свойствам горизонтов. В случае когда гипотеза Пирсона о наличии аномалий ВП над залежами углеводородов не вызывает сомнений - ДНМЭ может эффективно применяться для оконтуривания нефтегазоносных объектов. Электрическое сопротивление, определяемое по ДНМЭ, значительно отличается от ЗСБ. Для объяснения его петрофизической природы и корректного геологического истолкования требуется проведение специальных исследований. За счет влияния высокого сопротивления заземления (и соответственно малых токов в источнике), а также из-за влияния высокоомных пластов в разрезе, вероятно, глубинность ДНМЭ существенно ограничена.

С целью сравнения чувствительности методов К изменению параметров геоэлектрического разреза было проведено одномерное математическое моделирование. В качестве эталонных было выбрано 6 геоэлектрических моделей, характерных для результатов интерпретации ЗСБ и ДНМЭ. Проанализирована чувствительность кривых ДНМЭ к изменению элекгрического сопротивления, а также откликов ЗСБ к влиянию поляризуемости.

Кроме этого, приведены основные результаты математического моделирования сигналов нестационарного электромагнитного поля с учетом параметров индукционно-вызванной поляризации для установок ЗСБ петля-петля и петля-линия. Рассмотрены результаты работ методом ЗСБ с многокомпонентной регистрацией на одном из участков юга Сибирской платформы. 